\title{
Large scale purification of linear plasmid DNA for efficient high throughput cloning
}

\begin{tabular}{|c|c|}
\hline Journal: & Biotechnology Journal \\
\hline Manuscript ID: & biot.201000132.R1 \\
\hline Wiley - Manuscript type: & Technical Report \\
\hline $\begin{array}{r}\text { Date Submitted by the } \\
\text { Author: }\end{array}$ & 09-Jul-2010 \\
\hline Complete List of Authors: & $\begin{array}{l}\text { Noirclerc-Savoye, Marjolaine; Institut de Biologie structurale } \\
\text { Gallet, Benoit; Institut de Biologie Structurale } \\
\text { Bernaudat, Florent; Institut de Biologie Structurale } \\
\text { Vernet, Thierry; Institut de Biologie Structurale }\end{array}$ \\
\hline Primary Keywords: & linear vector \\
\hline Secondary Keywords: & high throughput cloning \\
\hline Keywords: & membrane protein, Mistic, Mono $\mathrm{Q}^{\mathrm{TM}}$ \\
\hline
\end{tabular}

\section{s) ScholaroNE \\ Manuscript Central}


1 Technical Report

2

3 Large scale purification of linear plasmid DNA for

4 efficient high throughput cloning

5

6 Marjolaine Noirclerc-Savoye ${ }^{\mathrm{a}, \mathrm{b}, \mathrm{c}}$, Benoit Gallet ${ }^{\mathrm{a}, \mathrm{b}, \mathrm{c}}$, Florent Bernaudat ${ }^{\mathrm{a}, \mathrm{b}, \mathrm{c}}$ and

7 Thierry Vernet ${ }^{\mathrm{a}, \mathrm{b}, \mathrm{c}}$

$8{ }^{a}$ CEA, Institut de Biologie Structurale Jean-Pierre Ebel, 41 rue Jules Horowitz

938027 Grenoble, France

$10{ }^{\mathrm{b}}$ CNRS, Institut de Biologie Structurale Jean-Pierre Ebel, Grenoble, France

$11{ }^{\mathrm{c}}$ Université Joseph Fourier, Institut de Biologie Structurale Jean-Pierre Ebel,

12 Grenoble, France

13

14

15 Keywords: linear vector, high throughput cloning, membrane protein, Mistic,

16 Mono $\mathrm{Q}^{\mathrm{TM}}$

17

18 Correspondence : Dr. Marjolaine Noirclerc-Savoye, Laboratoire d'Ingénierie des

19 Macromolécules, Institut de Biologie Structurale, 41 rue Jules Horowitz, 38027

20 Grenoble, France.

$21 \quad$ Fax. (33) 438785494.

22 E-mail : marjolaine.noirclerc@ibs.fr 
2 In this report we describe a rapid, simple, and efficient method for large

3 scale purification of linear plasmid DNA to answer demand from high throughput

4 gene cloning. The process is based on the separation of the linear vector from

5 small DNA fragments by anion exchange chromatography. Gene cloning

6 experiments by restriction/ligation or the In-Fusion ${ }^{\mathrm{TM}}$ technique confirmed the

7 high quality of the linearized vector as $100 \%$ of the genes were successfully

8 cloned.

9 


\section{$1 \quad 1$ Introduction}

2 Investigation of large numbers of proteins requires high throughput (HTP)

3 gene cloning approaches to prepare constructs that can be used for comprehensive

4 structural and functional analysis of proteins. Most methods do not require a

5 ligation step and these include Gateway cloning [1], Ligation Independent

6 Cloning (LIC) [2, 3] or In-Fusion ${ }^{\mathrm{TM}}$ [4], even though classical ligation-dependent

7 cloning has also been adapted to HTP [5].

8 Restriction/ligation and In-Fusion ${ }^{\mathrm{TM}}$ techniques are popular as they do not

9 require additional base pairs that convert into additional amino acids at the protein

10 extremities. The former method may be limited by the availability of unique

11 restriction sites. The latter one is more flexible as it allows in vitro assembly

12 through homologous recombination of fragments, providing that they include

13 extremities matching the sequences of the cloning site [4]. In that way, PCR

14 products can be cloned into any vector at any site of linearization. The success

15 rate of these techniques is strongly dependent on the quality of the linear vector.

16 For HTP approaches, the production of large batches of high quality linear vector

17 is of paramount importance. Small-scale purification is often based on gel

18 electrophoresis and spin column [6,7], two steps that are incompatible with the

19 production of large amount of DNA.

20 Plasmid DNA purification [8] has been the subject of many studies,

21 allowing large scale and high grade plasmid preparation [9-13], including the use

22 of anion exchange chromatography [14-17]. The separation of multiple small

23 restriction fragments by anion exchange chromatography on FPLC columns was 
1 previously described [18-20], showing a correlation between the size of linear

2 DNA fragments and the salt concentration needed for elution. For a given size,

3 substantial retardation of the $\mathrm{d}(\mathrm{A}+\mathrm{T})$ rich fragments has been reported [19]. Anion

4 exchange chromatography has also been used for plasmid adsorption, purification

5 and quantification $[9,15,21]$. We report here the use of anion exchange

6 chromatography for the large-scale purification of linear cloning vector and

7 separation from small restriction fragments. This application was first suggested

8 by Westman et al. [18], but to our knowledge, has never been described in the

9 literature.

10 Our protocol has been developed using two expression vectors specifically

11 constructed for an automated HTP approach to test the influence of purification

12 tags on the protein behavior: That is the presence or absence of His-tag for

13 soluble proteins, and of the His-Mistic-tag for membrane proteins. Membrane

14 proteins constitute up to $30 \%$ of all proteins $[22,23]$ and are involved in

15 numerous cellular processes. There are two bottlenecks in membrane protein

16 structural analysis: high-yield protein production and crystallization. Recently, a

17 novel membrane-associated protein discovered in Bacillus subtilis, Mistic, has

18 been shown to enhance the expression of recombinant membrane proteins in $E$.

19 coli, when fused to their N-terminus [24-26].

20 This article describes the purification of linearized expression vectors in

21 sufficient quantity and quality to efficiently perform hundreds of gene cloning in

22 parallel. This method offers a rapid and simple way to standard molecular

23 biology laboratories to prepare linear plasmid DNA on a large scale, and is a good 
1 alternative to multiple small scale preparations or expensive preparation from

2 commercial suppliers. 


\section{$1 \quad 2$ Materials and Methods}

$2 \quad 2.1$ pLIM13 and pLIM14 plasmids for high throughput cloning

3

4 derived from the commercial pET41c (Novagen) (Complete plasmid sequences

5 are available upon request). For pLIM13, the toxic $c c d B$ expression cassette [27]

6 was PCR amplified from pDEST17 (Invitrogen) and inserted into pET41c as an

$7 \quad$ NdeI-BamHI fragment (Figure 1). For pLIM14, a synthetic gene mistic- $c c d B$

8 (Geneart) was first inserted as an NdeI-BamHI fragment into pET41c. The

9 exchange of the XbaI-NdeI fragment of pET41c vector for one encoding a His6-

10 tag resulted in pLIM14 (Figure 1).

11 These pLIM plasmids are designed so that the linearization with two

12 restriction enzymes releases the toxic $c c d B$ expression cassette (Figure 1).

13 pLIM13 was designed to express proteins without tag, whereas pLIM14 was

14 designed to express His6- or His6-Mistic-tagged proteins, depending on the

15 restriction sites used to clone the corresponding genes (Figure 1).

\section{$17 \quad 2.2$ Large scale plasmid purification}

18 The pLIM13 and pLIM14 plasmids were prepared as previously described

$19[10,16]$ with some modifications. A $5 \mathrm{ml} 2 \mathrm{xTY}+\operatorname{kanamycin}(50 \mathrm{mg} / \mathrm{L})$

20 overnight culture of E. coli DB3.1 strain (Invitrogen) containing pLIM13 or

21 pLIM14 was used to inoculate $1 \mathrm{~L}$ of $2 \mathrm{xTY}+$ kanamycin $(50 \mathrm{mg} / \mathrm{L})$ into a $3 \mathrm{~L}$

22 flask. The culture was grown to saturation at $25^{\circ} \mathrm{C}$ for 36 hours, with $200 \mathrm{rpm}$ 23 shaking. 
To improve yield, the culture was separated in 4 fractions $(250 \mathrm{ml}$ each)

2 treated in parallel. Cells were harvested by centrifugation $\left(6200 \mathrm{~g}, 15 \mathrm{~min}, 4^{\circ} \mathrm{C}\right)$

3 and each pellet was resuspended in $40 \mathrm{ml}$ of GTE buffer (50 mM glucose, $25 \mathrm{mM}$

4 Tris/ $\mathrm{HCl} \mathrm{pH} \mathrm{8,} 10 \mathrm{mM}$ EDTA $)$ and $4 \mathrm{ml}$ of lysozyme $(25 \mathrm{mg} / \mathrm{ml})$. After $10 \mathrm{~min}$ at

5 room temperature, $20 \mathrm{ml}$ of a freshly prepared solution of $0.3 \mathrm{M} \mathrm{NaOH}$ and $2 \%$

6 SDS were added. The mixture was gently mixed by inverting the tubes 5 times,

7 and DNA denaturation was allowed to proceed $10 \mathrm{~min}$ on ice. Thirty $\mathrm{ml}$ of $3 \mathrm{M}$

8 potassium acetate $\mathrm{pH} 5.5$ were then added and mixed thoroughly by inverting the

9 tubes 5 times, to allow the renaturation of plasmid DNA and the precipitation of

10 chromosomal DNA, SDS-protein complexes and other cellular debris. This

11 mixture was incubated $10 \mathrm{~min}$ on ice before centrifugation $(19,000 \mathrm{~g}, 10 \mathrm{~min})$.

12 Supernatants containing plasmid DNA were pooled and passed through a funnel

13 filter before the addition of RNase A to a final concentration of $50 \mathrm{mg} / \mathrm{L}$ and

14 incubation at $37^{\circ} \mathrm{C}$ for $20 \mathrm{~min}$. Plasmid DNA was precipitated with the addition

15 of 0.6 volume of isopropanol and recovered after $20 \mathrm{~min}$ at room temperature by

16 centrifugation $(15,000 \mathrm{~g}, 10 \mathrm{~min})$. DNA pellet was washed once with $2 \mathrm{ml}$ of

$1770 \%$ ethanol, dried in a vertical laminar air-flow hood, and dissolved in $5 \mathrm{ml}$ of 5

$18 \mathrm{mM}$ Tris/HCl $\mathrm{pH}$ 8.5.

$20 \quad 2.3$ Large scale plasmid digestion

21 One hundred micrograms of plasmid DNA were digested in a $5 \mathrm{ml}$ final

22 volume in the presence of $500 \mu \mathrm{L}$ of buffer 4 (NEB), $50 \mu \mathrm{L}$ of BamHI HF (1000

$23 \mathrm{U}, \mathrm{NEB})$ and $100 \mu \mathrm{L}$ of $N d e \mathrm{I}(2000 \mathrm{U}, \mathrm{NEB})$ or $100 \mu \mathrm{L}$ of $N c o$ I (1000 U, NEB), at 
$137^{\circ} \mathrm{C}$ for 5 hours. Prior the addition of $\mathrm{NaCl}$ to a final concentration of $600 \mathrm{mM}$,

2 five $\mu \mathrm{L}$ of digestion product were analyzed by agarose gel electrophoresis.

\subsection{Linear vector isolation by Mono $Q^{\mathrm{TM}}$ anion exchange chromatography}

5 Chromatography was performed with an Äktabasic UPC apparatus (GE

6 Helthcare) and monitored at $254 \mathrm{~nm}$. The DNA sample was loaded at $1 \mathrm{ml} / \mathrm{min}$

7 onto a Mono $\mathrm{Q}^{\mathrm{TM}}$ 5/50 GL, (GE Healthcare) column equilibrated with buffer A

$8 \quad(10 \mathrm{mM}$ Tris/HCl $\mathrm{pH} 8,1 \mathrm{mM}$ EDTA, $700 \mathrm{mM} \mathrm{NaCl})$. After a wash at 0.5

$9 \mathrm{ml} / \mathrm{min}$ with $10 \mathrm{ml}$ of buffer A, a $64 \mathrm{ml}$ linear gradient of 0 to $10 \%$ buffer B (10

$10 \mathrm{mM}$ Tris/HCl $\mathrm{pH} 8,1 \mathrm{mM}$ EDTA, $2 \mathrm{M} \mathrm{NaCl}$ ) was applied at $0.15 \mathrm{ml} / \mathrm{min}$. Peak

11 fractions of $0.5 \mathrm{ml}$ were precipitated individually with the addition of 0.6 volume

12 of isopropanol. After 20 min room temperature, DNA pellets were recovered by

13 centrifugation $\left(21,000 \mathrm{~g}, 10 \mathrm{~min}, 4^{\circ} \mathrm{c}\right)$, washed with $70 \%$ ethanol and redissolved

14 in $50 \mu \mathrm{L}$ of $5 \mathrm{mM}$ Tris/ $\mathrm{HCl} \mathrm{pH}$ 8.5. Two $\mu \mathrm{L}$ of these fractions were analyzed on

$151 \%$ agarose gel. Fractions containing pure linear vector were pooled and assayed

16 in gene cloning experiments. Homogeneity and the sequence extremities of the

17 purified linear vector were checked by sequencing using the T7prom and T7term

18 primers.

$20 \quad 2.5$ Target genes amplification

21 Target genes were amplified by PCR using specific primers, designed with

22 the Vector NTI software (Invitrogen), containing 5' extensions related to the

23 vectors used for cloning. For pLIM13_NdeI_BamHI, the forward and the reverse 
1 primer extensions were respectively 5'-AAGGAGATATACATATG-3' and 5'-

2 TACAGAATTCGGATCCTTA-3', for pLIM14_NdeI_BamHI, 5'-

3 ACCATCACCATCATATG-3' and 5'-TACAGAATTCGGATCCTTA-3' and for 4 pLIM14_NcoI_BamHI, 5'-

5 CGGGCGGTAGCCATGGGGAAAATCTGTATTTTCAGGGC-3'(containing

6 protease TEV site) and 5'-TACAGAATTCGGATCCTTA-3'. These extensions

7 allow both restriction/ligation (using the underlined restriction sites) and InFusion

8 methods (relying on the extended sequence complementary to the vector).

9 Primers were ordered at $20 \mu \mathrm{M}$ in a 96-wells microplate (MWG). Preparation of

10 the $0.5 \mu \mathrm{M}$ primers mix and of the PCR reaction was fully automated on a

11 Microlab Star robot (Hamilton). Reactions were performed with $100 \mathrm{ng}$ of

12 chromosomal DNA template, $10 \mu \mathrm{L}$ of primer mix $0.5 \mu \mathrm{M}, 4 \mu \mathrm{L}$ of dNTPs 2.5

$13 \mathrm{mM}, 10 \mu \mathrm{L}$ of HF buffer $5 \mathrm{X}$ (Finnzyme), $0.5 \mu \mathrm{L}$ Phusion enzyme $(2 \mathrm{U} / \mu \mathrm{L}$,

14 Finnzyme) in a $50 \mu \mathrm{L}$ volume, using a Trobot PCR machine (Biometra) with the

15 following parameters : $98^{\circ} \mathrm{C}, 1 \mathrm{~min} ; 30$ cycles of $\left[98^{\circ} \mathrm{C}, 30 \mathrm{sec} ; 50^{\circ} \mathrm{C}, 30 \mathrm{sec}\right.$;

$\left.1672^{\circ} \mathrm{C}, 1 \mathrm{~min}\right] ; 72^{\circ} \mathrm{C}, 8 \mathrm{~min}$.

17 Five $\mu \mathrm{L}$ of each PCR product were analyzed on $1 \%$ agarose gel. Satisfying

18 PCR products (single or few multiple bands) were purified on a Nucleofast plate

19 (Macherey-Nagel) and eluted with $40 \mu \mathrm{L}$ of water, using a Microlab Star

20 automaton (Hamilton). 
1 Five $\mu$ Lof the PCR products were treated with Cloning Enhancer reagent

2 (In-Fusion ${ }^{\mathrm{TM}}$, Clontech) according to the supplier's recommendations. The In-

3 Fusion $^{\mathrm{TM}}$ reactions were performed by mixing $100 \mathrm{ng}$ of linear vector with $2 \mu \mathrm{L}$

4 of each treated insert ( $3 \mu \mathrm{L}$ for the 3501 bp-long insert) in $10 \mu \mathrm{L}$ final volume.

$5 \quad$ After the addition of $40 \mu \mathrm{L}$ of TE, $2.5 \mu \mathrm{L}$ of each reaction were used to transform

$650 \mu \mathrm{L}$ of NEB5 $\alpha$ competent $E$. coli cells (Biolabs). The transformed cells were

7 pelleted by centrifugation ( $5200 \mathrm{~g}, 5 \mathrm{~min}$ ) and spread onto LB (kanamycin 50

$8 \mathrm{mg} / \mathrm{L}$, glucose $10 \mathrm{mM}$ ) agar plates and incubated overnight at $37^{\circ} \mathrm{C}$.

9

\section{$10 \quad 2.7$ Cloning by restriction/ligation}

11 Forty $\mu \mathrm{L}$ of PCR products were mixed with $5 \mu \mathrm{L}$ buffer $410 \mathrm{X}$ (NEB), 0.5

$12 \mu \mathrm{L} N d e \mathrm{I}(10 \mathrm{U})$ or NcoI (5 U) and BamHI (5U) enzyme (NEB). After $2 \mathrm{~h}$ at

$1337^{\circ} \mathrm{C}$, fragments were purified on a Nucleofast plate (Macherey-Nagel) and eluted

14 with $40 \mu \mathrm{L}$ of water. Two $\mu \mathrm{L}$ of each insert were mixed with $100 \mathrm{ng}$ of linear

15 vector in the presence of $1 \mu \mathrm{L}$ of $10 \mathrm{X}$ T4 DNA ligation buffer, $1 \mu \mathrm{L}$ of T4 DNA

16 ligase $(3 \mathrm{U} / \mu \mathrm{L}$, Promega), in a final volume of $10 \mu \mathrm{L}$. After 3 hours at room

17 temperature, ligation reactions were stopped at $65^{\circ} \mathrm{C}(10 \mathrm{~min})$. Five $\mu \mathrm{L}$ were used

18 to transform $50 \mu \mathrm{L}$ of DH5 $\alpha$ competent $E$. coli cells. The transformed cells were

19 then pelleted before spreading on LB (kanamycin $50 \mathrm{mg} / \mathrm{L}$, glucose $10 \mathrm{mM}$ ) agar

20 plate and incubated overnight at $37^{\circ} \mathrm{C}$.

21

$22 \quad 2.8$ Plasmid screening by restriction analysis 
1 Isolated transformants were used to inoculate $2 \mathrm{ml}$ of 2 XTY (50 mg/L

2 kanamycin) medium in a 24-wells plates sealed with a porous film. Cultures were

3 grown for $20 \mathrm{~h}$ at $37^{\circ} \mathrm{C}$ with agitation $(200 \mathrm{rpm})$. Cells were pelleted and

4 plasmids were prepared on a Qiagen BioRobot 8000 using the Nucleospin robot

596 kit (Macherey-Nagel) and eluted with $125 \mu \mathrm{L}$ of EB buffer. Eight $\mu \mathrm{L}$ were

6 used for restriction analysis with $2.5 \mathrm{U}$ of each enzyme in a final volume of 10

$7 \quad \mu \mathrm{L}$; profiles were analyzed on $1 \%$ agarose gel. Two positive clones for each gene

8 were sent for full length sequencing with the universal T7 prom and T7 term

9 primers (Beckman Cogenics). Sequencing with internal primers was necessary

10 for genes longer than $2 \mathrm{~Kb}$. 


\section{$1 \quad 3$ Results and discussion}

3 commonly used method of purification is preparative gel electrophoresis followed

4 by spin column extraction [6]. Both steps are poorly suited to large amounts of

5 DNA. To overcome this limitation, we have scaled up the separation of

6 restriction fragments by anion exchange chromatography [18].

$8 \quad 3.1$ Construction of expression vectors for soluble or membrane proteins

9 expression

10 Two expression plasmids were designed to express soluble or membrane

11 proteins, with the same backbone vector. The pLIM13 vector allows expression

12 of proteins without tag, whereas pLIM14 is for His6- or His6-Mistic-fusion for

13 soluble or membrane proteins respectively. The Mistic protein from B. subtillis

14 was shown to increase the yield by targeting fused proteins more efficiently to the

15 membrane in E. coli [24], (F. Bernaudat, personal observations). The toxic $c c d B$

16 gene was inserted between the restrictions sites used for linearization (Figure 1).

17 The CcdB protein is a poison of the DNA-topoisomerase II complexes killing

18 bacterial strains not expressing the antidote CcdA [28], or not containing the

19 gyrA462 mutation $[28,29]$. The interest of $c c d B$ is to select against the parental

20 vector in E. coli sensitive strains.

21 Digestion of pLIM13 with NdeI and BamHI produces two fragments of

225082 bp and 311 bp. Digestion of pLIM14 with the same enzymes gives $5103 \mathrm{bp}$

23 and $683 \mathrm{bp}$ fragments, whereas digestion with $\mathrm{NcoI}$ and BamHI releases $5455 \mathrm{bp}$ 
1 and $331 \mathrm{bp}$ fragments. The larger fragments are the linearized vectors, the small

2 fragments contain the $c c d B$ gene. These digestions allow the in frame insertion of

3 any gene amplified with specific primers (see Materials and Methods and Figure

$4 \quad 1)$.

5

$6 \quad 3.2$ Large scale plasmid purification

7 The protocol for purification of large amount of pLIM13 and pLIM14 was

8 derived from known procedures [10, 16], and yielded $1.8 \mathrm{mg}$ of each low copy

9 vector from $1 \mathrm{~L}$ of the $\mathrm{CcdB}$ resistant DB3.1 E. coli strain grown in $2 \mathrm{xTY}$. The

10 purified plasmid was mostly supercoiled, with the presence of a minor nicked

11 DNA form and no detectable RNA or protein contamination. The yield was

12 sufficient for the preparation of 18 batches of linear vector as described below.

$14 \quad$ 3.3 Large-scale linear plasmid purification by Mono $Q^{\mathrm{TM}}$ anion exchange 15 chromatography

16 This procedure succeeded with the three linearized pLIM vectors. The

17 purification of pLIM13 digested with $N d e \mathrm{I}$ and BamHI is presented in details

18 below as an example.

19 One hundred micrograms of pLIM13 were digested and the $\mathrm{NaCl}$

20 concentration was brought to $600 \mathrm{mM}$ prior to the chromatography to avoid

21 adsorption of low charge density impurities on the Mono $\mathrm{Q}^{\mathrm{TM}}$ column [15]. The

22 advantage of a Mono $\mathrm{Q}^{\mathrm{TM}}$ resin is the fast and strong binding of the DNA (Figure

23 2) [21]. 
1 A salt gradient was employed to displace the different nucleic acids that

2 should elute in order of increasing charge density [15]. The charge density of

3 DNA is function of its length and conformation. Long fragments, being more

4 folded, have higher charge densities and are eluted later. The separation was

5 visualized by the detection of two peaks and confirmed by the agarose gel

6 analysis (Figure 2). Fractions containing the linearized expression vector were

7 pooled. A third early peak corresponded to the elution of restriction enzymes

\section{$9 \quad 3.4$ Quality control of linear plasmid}

10 One hundred nanograms of each vector (pET41c, pLIM13, and pLIM14)

11 were transformed into NEB5 $\alpha$ and DH5 $\alpha$. In both strains, approximately one

12 thousand transformants were obtained with pET41c and none with pLIM13 as

13 expected due to the presence of the $c c d B$ gene in the latter plasmid. To our

14 surprise, thousand transformants were also obtained with the pLIM14. As $c c d B$ is

15 still present, we hypothesize that the normally cytosolic CcdB protein is not

16 functional when fused to Mistic and targeted to the membrane. However, this

17 finding allowed us to evaluate the homogeneity of the purified linear vector, as we

18 could compare the number of transformants obtained with the native and the

19 linearized plasmid. Linearized pLIM14 yielded no transformant showing the

20 absence of undigested parental vector.

21 The quality and quantity of the linear vectors isolated by Mono $\mathrm{Q}^{\mathrm{TM}}$

22 chromatography are suitable for high throughput cloning, even if yields vary with

23 the vectors and the digestions. Yields after digestions and purification were $26 \%$ 
$1(25 \mu \mathrm{g}), 43 \%(38 \mu \mathrm{g})$ or $73 \%(69 \mu \mathrm{g})$ for pLIM13_NdeI_BamHI,

2 pLIM14_NdeI_BamHI and pLIM14_NcoI_BamHI, respectively. Individual

3 fraction precipitations and pooling are probably responsible for the loss of

4 material.

5

$6 \quad 3.5$ Efficient cloning with linear plasmid

$7 \quad$ The suitability for high throughput cloning of the purified

8 pLIM13_NdeI_BamHI linearized vector was tested by the insertion 24

9 independent genes in parallel. The gene size varied between $387 \mathrm{bp}$ and $3501 \mathrm{bp}$.

10 Eleven genes were cloned by restriction/ligation and 13 using the In-Fusion ${ }^{\mathrm{TM}}$

11 technique. Genes containing restriction sites within their sequence were treated

12 by the In-Fusion ${ }^{\mathrm{TM}}$ method.

13 The automated PCR amplification of the 24 genes was performed with the

14 Phusion enzyme on a Hamilton robot. PCR products were analyzed on agarose

15 gel (Figure 2) and showed the successful amplification of all the genes using the

16 same PCR parameters. Purification on a Nucleofast plate eliminated primer

17 dimers and allowed buffer exchange.

18 Genes to be treated by ligation were first digested with the two appropriate

19 restriction enzymes, and purified again on Nucleofast to eliminate the short

20 fragments released by the digestion. Genes destined to In-Fusion ${ }^{\mathrm{TM}}$ cloning were

21 directly incubated with the Cloning Enhancer according the manufacturer's

22 recommendations. 
$1 \quad$ With both cloning methods, $100 \mathrm{ng}$ of linear vector were mixed to $2-3 \mu \mathrm{L}$ of

2 insert. We have deliberately chosen to standardize the volume of insert,

3 independently of their size, in order to develop an efficient high throughput

4 process for a wide range of gene sizes, as the amplification delivers PCR

5 fragments in amounts that are not limiting. After ligation or In-Fusion ${ }^{\mathrm{TM}}$

6 recombination, transformation suspensions were platted on agar containing

7 kanamycine, and glucose to repress the expression leakage.

8 Between 20 and 100 transformants were obtained, without relationship

9 between the size of the insert and the number of transformants. For the negative

10 control (linear pLIM13 plasmid without insert), around 10 and 70 transformants

11 were obtained. These transformants resulted from aberrant recombination events.

12 To evaluate the cloning success rate, 2 to 8 transformants were analyzed for each

13 of the 24 genes by plasmids miniprep followed by restriction mapping.

14 The 24 genes were successfully cloned in parallel into the expression vector

15 indicating the good quality of the linear vector preparation (Table 1). Cloning

16 efficiencies were not correlated to the size of the gene, although the most difficult

17 gene to clone was the longest (3501 bp). Except in the latter case, $50 \%$ to $100 \%$

18 of positive clones were obtained for all other genes. The negative clones resulted

19 apparently from aberrant recombination events, such as the clones obtained from

20 the negative controls. The mean cloning efficiency by restriction/ligation was

$2163 \%$, whereas that obtained by In-Fusion ${ }^{\mathrm{TM}}$ was $80 \%$ including the lower yield

22 obtained with the longest gene. The systematic full length gene sequencing 
1 performed on two positive clones of each gene, showed the absence of mutation

2 with a single exception likely originating from a PCR error.

44 Concluding remarks

5 Large amount of linear expression vector is obtained by separating the

6 vector from its insert by anion exchange chromatography. The cloning results

7 indicate that the quality of the linear vector purified by Mono $\mathrm{Q}^{\mathrm{TM}}$ is compatible

8 with different high throughput cloning techniques. However, the In-Fusion ${ }^{\mathrm{TM}}$

9 technique is, in our view, better adapted to high throughput as this system

10 catalyzes the joining of DNA pieces in a manner that is independent of the

11 sequence of the cloned gene.

12

13 We thank André Zapun for critical reading of the manuscript. This work

14 was partly supported by the European grant LSMH-CT-EUR-INTAFAR 2004-

15512138 and the ANR-FORM-080124-01-01. This work was performed on the

16 RoBioMol Platform at the IBS (Grenoble), which belongs to the Partnership for

17 Structural Biology (PSB).

18

19 The authors have declared no conflict of interest. 


\section{$1 \quad$ 5. References}

2 [1] Busso, D., Delagoutte-Busso, B., Moras, D., Construction of a set Gateway-

3 based destination vectors for high-throughput cloning and expression screening in

4 Escherichia coli. Analytical biochemistry 2005, 343, 313-321.

5 [2] Geertsma, E. R., Poolman, B., High-throughput cloning and expression in

6 recalcitrant bacteria. Nature methods 2007, 4, 705-707.

7 [3] Qin, H., Hu, J., Hua, Y., Challa, S. V., et al., Construction of a series of

8 vectors for high throughput cloning and expression screening of membrane

9 proteins from Mycobacterium tuberculosis. BMC biotechnology 2008, 8, 51.

10 [4] Berrow, N. S., Alderton, D., Sainsbury, S., Nettleship, J., et al., A versatile

11 ligation-independent cloning method suitable for high-throughput expression

12 screening applications. Nucleic acids research 2007, 35, 1-12.

13 [5] Klock, H. E., White, A., Koesema, E., Lesley, S. A., Methods and results for

14 semi-automated cloning using integrated robotics. Journal of structural and

15 functional genomics 2005, 6, 89-94.

16 [6] Berrow, N. S., Alderton, D., Owens, R. J., The precise engineering of

17 expression vectors using high-throughput In-Fusion PCR cloning. Methods in

18 molecular biology (Clifton, N.J 2009, 498, 75-90.

19 [7] Weeks, S. D., Drinker, M., Loll, P. J., Ligation independent cloning vectors

20 for expression of SUMO fusions. Protein expression and purification 2007, 53, $21 \quad 40-50$.

22 [8] Sambrook, J., Fritsch, E. F., Maniatis, T., Molecular Cloning. A laboratory 23 manual, 1989. 
1 [9] Ferreira, G. N., Monteiro, G. A., Prazeres, D. M., Cabral, J. M., Downstream

2 processing of plasmid DNA for gene therapy and DNA vaccine applications.

3 Trends in biotechnology 2000, 18, 380-388.

4 [10] Heilig, J. S., Elbing, K. L., Brent, R., Large-scale preparation of plasmid

5 DNA. Current protocols in molecular biology / edited by Frederick M. Ausubel ...

6 [et al 2001, Chapter 1, Unit1 7.

7 [11] Stadler, J., Lemmens, R., Nyhammar, T., Plasmid DNA purification. The

8 journal of gene medicine 2004, 6 Suppl 1, S54-66.

9 [12] Levy, M. S., O'Kennedy, R. D., Ayazi-Shamlou, P., Dunnill, P., Biochemical

10 engineering approaches to the challenges of producing pure plasmid DNA. Trends

11 in biotechnology 2000, 18, 296-305.

12 [13] Chakrabarti, A., Sitaric, S., Ohi, S., A procedure for large-scale plasmid

13 isolation without using ultracentrifugation. Biotechnology and applied

14 biochemistry 1992, 16, 211-215.

15 [14] Hines, R. N., O'Connor, K. C., Vella, G., Warren, W., Large-scale

16 purification of plasmid DNA by anion-exchange high-performance liquid

17 chromatography. BioTechniques 1992, 12, 430-434.

18 [15] Diogo, M. M., Queiroz, J. A., Prazeres, D. M., Chromatography of plasmid

19 DNA. J Chromatogr A 2005, 1069, 3-22.

20 [16] Prazeres, D. M., Schluep, T., Cooney, C., Preparative purification of

21 supercoiled plasmid DNA using anion-exchange chromatography. J Chromatogr

22 A 1998, 806, 31-45. 
1 [17] Smrekar, F., Podgornik, A., Ciringer, M., Kontrec, S., et al., Preparation of

2 pharmaceutical-grade plasmid DNA using methacrylate monolithic columns.

3 Vaccine, 28, 2039-2045.

4 [18] Westman, E., Eriksson, S., Laas, T., Pernemalm, P. A., Skold, S. E.,

5 Separation of DNA restriction fragments by ion-exchange chromatography on

$6 \quad$ FPLC columns Mono P and Mono Q. Analytical biochemistry 1987, 166, 158-

$7 \quad 171$

8 [19] Muller, W., Fractionation of DNA restriction fragments with ion-exchangers

9 for high-performance liquid chromatography. European journal of biochemistry /

$10 \quad$ FEBS 1986, 155, 203-212.

11 [20] Wells, R. D., Hardies, S. C., Horn, G. T., Klein, B., et al., RPC-5 column

12 chromatography for the isolation of DNA fragments. Methods in enzymology

$131980,65,327-347$.

14 [21] Tiainen, P., Galaev, I., Larsson, P. O., Plasmid adsorption to anion-exchange

15 matrices: comments on plasmid recovery. Biotechnology journal 2007, 2, 726-

16735.

17 [22] Wallin, E., von Heijne, G., Genome-wide analysis of integral membrane

18 proteins from eubacterial, archaean, and eukaryotic organisms. Protein Sci 1998,

$197,1029-1038$.

20 [23] Boyd, D., Schierle, C., Beckwith, J., How many membrane proteins are

21 there? Protein Sci 1998, 7, 201-205.

22 [24] Kefala, G., Kwiatkowski, W., Esquivies, L., Maslennikov, I., Choe, S.,

23 Application of Mistic to improving the expression and membrane integration of 
1 histidine kinase receptors from Escherichia coli. Journal of structural and

2 functional genomics 2007, 8, 167-172.

3 [25] Roosild, T. P., Greenwald, J., Vega, M., Castronovo, S., et al., NMR

4 structure of Mistic, a membrane-integrating protein for membrane protein

5 expression. Science (New York, N.Y 2005, 307, 1317-1321.

6 [26] Roosild, T. P., Vega, M., Castronovo, S., Choe, S., Characterization of the

7 family of Mistic homologues. BMC structural biology 2006, 6, 10.

8 [27] Bahassi, E. M., Salmon, M. A., Van Melderen, L., Bernard, P., Couturier, M.,

9 F plasmid CcdB killer protein: ccdB gene mutants coding for non-cytotoxic

10 proteins which retain their regulatory functions. Molecular microbiology 1995,

$11 \quad 15,1031-1037$.

12 [28] Afif, H., Allali, N., Couturier, M., Van Melderen, L., The ratio between

$13 \mathrm{CcdA}$ and $\mathrm{CcdB}$ modulates the transcriptional repression of the ccd poison-

14 antidote system. Molecular microbiology 2001, 41, 73-82.

15 [29] Bernard, P., Couturier, M., Cell killing by the F plasmid CcdB protein

16 involves poisoning of DNA-topoisomerase II complexes. Journal of molecular

17 biology 1992, 226, 735-745.

18

19 


\section{Figure legends}

2 Figure 1. pLIM vector maps. Linearization of the vectors was performed using

3 the restriction sites mentioned. PCR-amplified genes were inserted either by

4 restriction ligation or by the In-Fusion ${ }^{\mathrm{TM}}$ method. (A) pLIM13 for the

5 overexpression of untagged proteins; (B) pLIM14 for the overexpression of His-

6 tagged (cloned between the NdeI and BamHI sites) or His-Mistic-tagged proteins

7 (cloned between $\mathrm{NcoI}$ and BamHI). The T7 promoter induces expression in $E$.

8 coli harbouring the $\lambda$ (DE3) prophage.

10 Figure 2. Linear plasmid purification by Mono $\mathbf{Q}^{\mathrm{TM}}$ anion exchange

11 chromatography and PCR amplification of the $\mathbf{2 4}$ genes used in cloning

12 experiments. (A) Chromatogram showing the purification of pLIM13 digested

13 with NdeI and BamHI monitored at $254 \mathrm{~nm}$. Plasmids were loaded on a Mono

$14 \mathrm{Q}^{\mathrm{TM}} 5 / 50 \mathrm{GL}$ column. DNA was eluted with a $64 \mathrm{ml}$ linear gradient of $700 \mathrm{mM}$

$15(0 \% \mathrm{~B})$ to $900 \mathrm{mM}(10 \% \mathrm{~B})$ of $\mathrm{NaCl}$ at $0.15 \mathrm{ml} / \mathrm{min}$. Arrows indicate the

16 fractions analyzed. (B) $1 \%$ Agarose gel analysis of the fractions corresponding to

17 the elution peaks shown in (A): M, DNA ladder; 1, loaded sample; 2, flow

18 through (pooled fractions $2-4$ ); 3 to 6 , fractions corresponding to the $c c d B$ insert;

197 to 15 , fractions corresponding to the linear vector. (C) $1 \%$ Agarose gel analysis

20 of the pooled elution fractions from the chromatographic separations of

21 pLIM14_NdeI_BamHI: 1, Mistic-ccdB insert; 2, linear vector; and

22 pLIM14_NcoI_BamHI: 3, ccdB insert; 4, linear vector. (D) 1\% Agarose gel

23 analysis of the PCR amplification of 24 independent genes. M, DNA ladder; 1 to 
124, PCR amplification obtained in the conditions described in Materials and

2 Methods section and successfully cloned into pLIM13_NdeI_BamHI: 
1 Table 1. Gene cloning using pLIM13_NdeI-BamHI linear vector by

2 restriction/ligation or InFusion techniques

\begin{tabular}{|c|c|c|c|c|}
\hline Gene number & Plasmid & $\begin{array}{l}\text { Technique } \\
\text { used }\end{array}$ & Insert size (bp) & $\begin{array}{l}\% \text { of positive clones } \\
\text { ( Nb clones tested) }\end{array}$ \\
\hline 1 & pLIM13 & Ligation & 1233 & $50 \%(4)$ \\
\hline 2 & pLIM13 & Ligation & 1131 & $50 \%(4)$ \\
\hline 3 & pLIM13 & Ligation & 1683 & $75 \%(4)$ \\
\hline 4 & pLIM13 & Ligation & 816 & $50 \%(4)$ \\
\hline 5 & pLIM13 & Ligation & 657 & $50 \%(4)$ \\
\hline 6 & pLIM13 & InFusion & 627 & $87 \%(8)$ \\
\hline 7 & pLIM13 & InFusion & 600 & $100 \%(8)$ \\
\hline 8 & pLIM13 & Ligation & 672 & $75 \%(4)$ \\
\hline 9 & pLIM13 & InFusion & 3501 & $37 \%(8)$ \\
\hline 10 & pLIM13 & InFusion & 603 & $100 \%(8)$ \\
\hline 11 & pLIM13 & InFusion & 1950 & $50 \%(8)$ \\
\hline 12 & pLIM13 & InFusion & 1887 & $75 \%(8)$ \\
\hline 13 & pLIM13 & Ligation & 1962 & $100 \%(4)$ \\
\hline 14 & pLIM13 & InFusion & 1557 & $75 \%(8)$ \\
\hline 15 & pLIM13 & Ligation & 456 & $100 \%$ \\
\hline 16 & pLIM13 & InFusion & 1119 & $55 \%(9)$ \\
\hline 17 & pLIM13 & InFusion & 843 & $100 \%$ \\
\hline 18 & pLIM13 & InFusion & 837 & $87 \%$ (8) \\
\hline
\end{tabular}




\begin{tabular}{|lllcl}
19 & pLIM13 & Ligation & 489 & $50 \%(4)$ \\
20 & pLIM13 & Ligation & 387 & $50 \%(2)$ \\
21 & pLIM13 & InFusion & 1116 & $100 \%(3)$ \\
22 & pLIM13 & InFusion & 1302 & $100 \%(8)$ \\
23 & pLIM13 & Ligation & 1038 & $50 \%(2)$ \\
24 & pLIM13 & InFusion & 1059 & $100 \%(8)$ \\
\hline
\end{tabular}


A

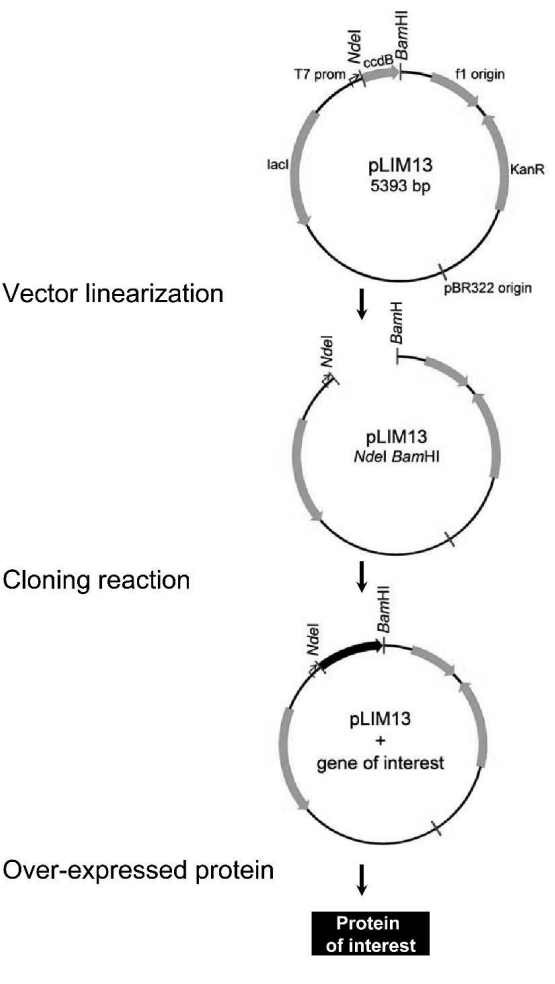

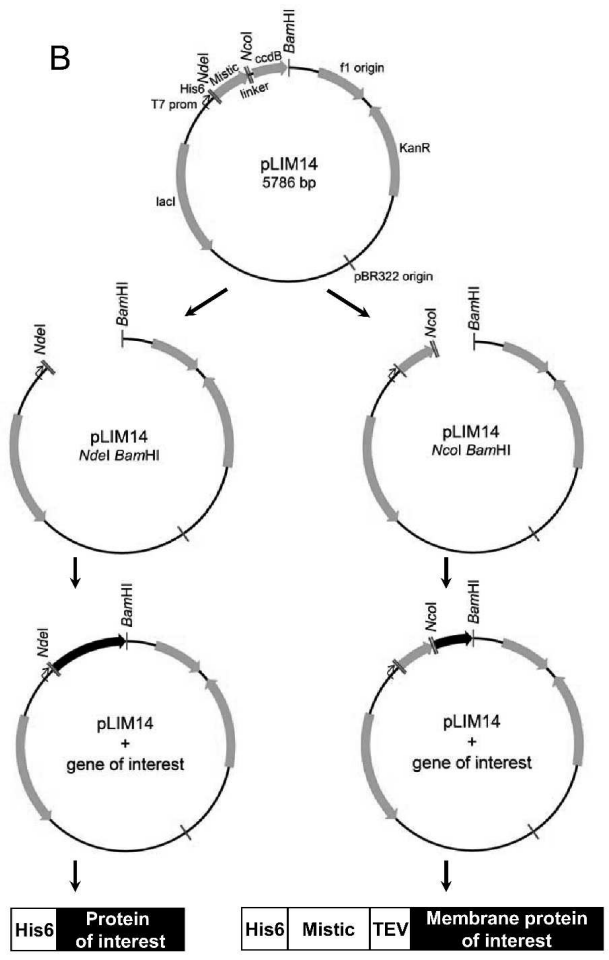

$245 \times 180 m m(600 \times 600$ DPI $)$ 


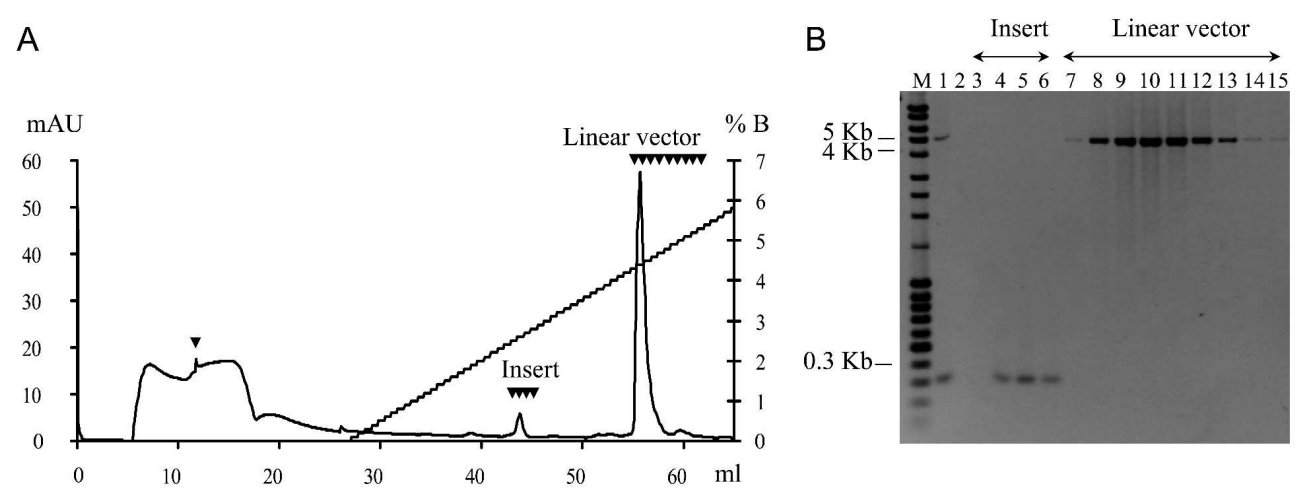
C

D
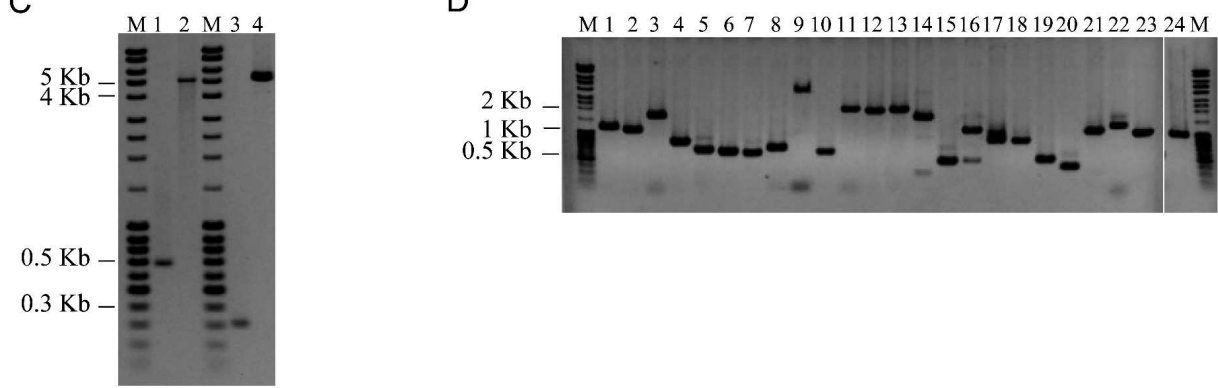

$250 \times 179 \mathrm{~mm}(600 \times 600 \mathrm{DPI})$ 